\title{
Analysing Change: Complex rather than Dialectical?
}

Erika Cudworth

Stephen Hobden

University of East London

This article offers a discussion of dialectics from a complexity perspective. Dialectics is a term much utilized but infrequently defined. This article suggests that a spectrum of ideas exist concerning understandings of dialectics. We are particularly critical of Hegelian dialectics which we see as anthropocentric and teleological. While Marxist approaches to dialectics, in the form of historical materialism, marked a break from the idealist elements of Hegelian dialectics they retained traces of this approach. The article offers a partial discussion of essential elements of dialectics, which we consider to be the analysis of change, the centrality of contradiction and the methodology of abstraction. Points of overlap with complexity thinking are highlighted together with those points where complexity thinking and dialectical approaches diverge. We conclude with some suggestions of how complexity thinking might contribute to a development of dialectical approaches. 


\section{Introduction}

The purpose of this article is to query the status of dialectics. We write from a perspective informed by complexity thinking. We seek not to undermine dialectics, but rather to raise questions about dialectics that become apparent from a complexity perspective. In fact we see many parallels between dialectics and complexity. So we do not dismiss dialectics, but rather seek to expand upon the basis of dialectics. We see our critique as the basis of a friendly conversation rather than a denunciation. Engaging with complexity may enhance dialectics by providing a less restricted account of experience.

The article is divided into three sections. In the first we provide an account of our understanding of dialectics. A problem of providing any account of dialectics is that the term has been used in a variety of ways. As a result, to quote Ollman and Smith (2008, p. 4) 'practically every aspect of it is contested'. In a relatively short article it is not possible to do justice to the varieties of discussions of dialectics, and we would acknowledge at the outset that our account will be partial in more than one sense of the word: a full account of dialectics would involve writing several books; and any account will reflect the bias of the authors. Hence we do not claim to provide either a complete or an unbiased account of dialectics - but at least the reader will be provided with an outline of how we understand the term.

In the second part of the article we draw attention to the points of contact between complexity thinking and dialectics. There are a 
number of features of dialectics that we would endorse. Reality in dialectics is seen as in a state of perpetual flux, and part of dialectical analysis is the attempt to understand those processes of change. Furthermore several accounts of dialectics indicate that it provides an attempt to grapple with the essentially chaotic features of the world. This is a feature that the writings of Marx \& Engels would appear to acknowledge, and has been one of the key preoccupations of complexity thinking. There are, however, features of dialectics of which we are more critical. We point to three areas where complexity thinking would have problems with dialectics. Firstly, most accounts of Hegel's view of dialectics depict his system as teleological. While many subsequent authors argue that their perspectives on dialectics are non-teleological, we are sceptical about whether, given the Hegelian influence on dialectical thinking, all traces of the teleological heritage have been eradicated. Secondly, most, although admittedly not all, accounts of dialectics focus on the notion of contradiction as the driving force of dialectical processes. While we would not deny that there are contradictions, nor that these generate change, it is here that we would make the claim that dialectics only gives us a limited perspective. Again we need to consider what is meant by contradiction, however we would argue that change can also occur in a non-contradictory, co-evolutionary way. The emphasis on contradiction probably results from the influence of a reading of Darwin which sees evolutionary change as a question of 'survival of the fittest'. We would argue that this is a limited reading of Darwin, 
and would also draw on Kroptkin's work on mutality. Our final point of criticism would be that most discussions and applications of dialectics are inherently anthropocentric. This may be an inevitable feature of dialectics - and certainly Hegelian dialectics could only be anthropocentric. Again we would argue that the result of this anthropocentrism is to provide only a limited (that is, inter-human) perception.

In the third section we make some suggestions as to how complexity thinking could potentially provide a means of overcoming some of the issues raised in third section. Complexity thinking is also highly contested, and the version of complexity that we advocate draws heavily on the work of Edgar Morin. In this section we point to features of complexity thinking that we consider to be absent from dialectical approaches. In particular we will discuss the coevolutionary character of relations between systems, feedback loops, and the possibility, drawing on the work of Gunderson and Holling, of analysing human and non-human systems as a way of subverting anthropocentrism.

We will conclude by stating the commitment of our particular project, which we have called posthuman international relations, to the significance of exposing forms of exclusion both within the social world and in human non-human interactions. While we offer a critique of certain elements of dialectics we support the emancipatory projects that motivate many of those who adhere to dialectical approaches. 


\section{The Essential Elements of Dialectics}

For Allen Wood (1993, p. 416), 'the dialectic treats the world as a complex of processes rather than things, reveals everything as shot through with tensions and contradictions demanding resolution and hence to be transitory, and involved in an inevitably progressive process of development'. This definition provides an overview of several features that we examine in this section. These are the analysis of reality as a totality, the centrality of change, the importance of contradiction, the use of abstraction, and the centrality of immanence.

\section{Change}

That the world is in a constant state of flux is a central idea within dialectical approaches. At one level this might not seem to be a particularly radical claim, as we are constantly aware of changes around us. However, as Bill (2008, p. 133) points out 'most people have great difficulty grasping the reality of change... this is largely the result of operating with a conception of human nature that views people as fixed in space'. To counter such a view raises serious epistemological questions. A key element of positivist approaches is that the world is made up of regularities and continuities. We know about the world because we are able to observe its regularities, and when certain events occur (for example, the breakdown of the balance 
of power) we can expect certain outcomes (conflict). In a world of constant change these regularities don't exist, and hence dialectical claims about change imply that we need to consider other methodologies for understanding the world. According to Rees (1998, p. 6) 'change, development, instability, on the other hand, are the very conditions for which a dialectical approach is designed to account', and this point was emphasized by Engels (cited in Rees, 1998, p. 6) when he noted that 'the whole world, natural, historical intellectual, is represented as a process, i.e., as in constant motion, change, transformation, development.... the history of mankind no longer appeared as a wild whirl of senseless deeds of violence.... but as a process of evolution of man himself'. In other words, instead of taking things as they appear as positivist approaches imply, 'nothing can be seen as merely what it is, or appears to be' (Kovel, 2008, p. 239).

These forms of change are evident across all levels of existence from the material to level of consciousness. Hence for Marx (1976 [1873], p. 103), the central focus was on the development of the material forces of production, which had an impact on the character of consciousness. For Hegel, by contrast, the historical process was one of an increasing alignment between consciousness and the material world as humanity moved towards absolute knowledge. This was a rational process that could be understood scientifically, as Buchwalter (2012, p. 5) notes, 'Hegel's practical philosophy culminates in a theory of world history understood as progress in the consciousness and self-consciousness of freedom' (also see Rees, 1998, p. 41). What has 
perhaps not been fully resolved is whether this process of change is in some way teleological or purposeful. For Hegel it certainly was teleological - a process of moving towards absolute knowledge. Also noteworthy is that in the quote from Engels cited above, he talks of a process of 'evolution of man himself' - although we can't be sure that he used the term evolution in a directed sense in this instance.

\section{Totality}

In addition to the notion of constant change, a core element of dialectical thinking is the notion of the requirement to analyse a totality. As with the analysis of change, this provides another contrast with positivist accounts. Positivism suggests that the world can be separated into distinct parts that can then be analysed separately. Such an approach is often described as reductionist - the view that analysis can proceed from examining one unit and then combining that with the analysis of a separate unit. The perception is that individuals are discrete units whose actions can be understood independently of a greater whole. The character of western academia with its division into separate disciplines of, for example, economics, politics and sociology, is premised on the notion that the social world can be carved up and examined in different sections. From a dialectical perspective this makes little sense, and reality has to be examined as a whole. This is because the parts cannot be seen as operating independently of the whole. Every unit is impacted by those 
around it and is affected by the structures that those interactions comprise. Wholes and parts create a web of interactions, which means that to look at one simple part will mean overlooking the influences of the other parts with which any single unit interacts, and crucially the total context in which interactions occur.

Examining the totality 'for Hegel, means grasping the parts as mediated and transformed by their interplay with the whole, and equally of the whole as mediated and transformed by its interplay with the parts' (Creavan, 2007, p. 73). In other words, it is not a case of just examining the parts and the wholes, but of understanding that there is an inter-relationship between the parts and wholes so that both have an influence on each other. Hence for Marx, the social totality was the capitalist system (Jameson, 2008, p.125) and the interaction of any part of the capitalist system could not be completely understood without taking the overall context of capitalist relations into account. Likewise the capitalist system could only be understood by including an analysis of the interactions between individual capitalists and proletariat.

What is potentially more of a problem is defining what that totality might be. Expanding the concept of the totality would clearly have implications for analysis. Is the totality a particular society (which is what it is apparently for Hegel), or is it the capitalist system (which is what the total unit of analysis appears to be for Marx)? Could it be the total of humanity, or is it possible to see the totality as the inter- 
relations between species, or the total inter-relations within the biosphere, or potentially even further?

The requirements to take into account the processes of change and the need to analyse the social whole as a totality are interconnected, and together imply the need for a form of analysis that doesn't perceive the world of independent units whose central characteristic is their stability. Ollman (1993, p. 11) summarises the contribution that dialectics contributes to resolving this problem 'by expanding our notion of anything to include, as aspects of what it is, both the process by which it has become that and the broader interactive context in which it is found.' This leads to a further two features of dialectical analysis.

\section{Contradiction}

So far we have seen the significance of understanding the totality as far as a dialectical analysis is concerned, and that everything within the totality is in a state of flux. For dialectical thinking contradiction is the driving force for this continual change. For Hegel (cited in Creavan, 2007, p. 75), 'contradiction is at the root of all movement and life, and it is only in so far as it contains a contradiction that anything moves and has impulse and activity.' Ultimately, if we want to understand the processes of change then we need to understand the contradictions between different elements. While for Hegel, consciousness was the level at which contradictions 
occurred - normally summarized as the development of a pattern of thesis - antithesis - synthesis, for Marx, contradictions played out at a material level. For Marx, 'analysis starts out from real, material, empirically verifiable contradictions. The forces involved are not merely ideas or even ideologies, though these are also present, but real economic and political institutions, classes, parties' (Rees, 1998, p. 83).

The working out of contradictions is not just about resolving differences, or one element of the contradiction overcoming the other. Both parts of the contradiction are changed as a result of the process of resolving contradictions, with the new element that arises containing elements of both. Hegel referred to this as the 'negation of the negation', a process whereby 'new and distinct situations arise from contradictory circumstances in such a way that that aspects of the old circumstances appear, transformed, as part of the new conditions' (Rees 1998, p. 9). This also involved a forward progressive movement for Hegel, with each occurrence of the negation of the negation in the science of logic placing 'the absolute under a more comprehensive, more nearly true identifying description' (Butler, 2012, p. 23).

Perhaps the most famous such contradiction from a Marxist perspective is that of class conflict. Differences between classes, specifically between an exploiting and an exploited class, drive the onwards movement of history. A communist society would involve the final resolution of such a contradiction with the appearance of a 
classless society. This was not, then, simply a case of one class winning out over the other, but of both classes being transformed in the process of resolving the contradictions.

As Shannon Brincat (2010, p. 681) notes 'the dialectical tradition is characterized by its ontological focus on change through contradiction.' Hence the concept of contradiction is central to analyzing the historical process, and Jameson (2008, p. 128) argues that when one fails to see contradictions that one has stopped thinking dialectically. It is the working out of contradictions that drives the historical process further. This would appear to have a progressive element to it. Hegel's views were certainly teleological in that the working out of contradictions moves consciousness forwards to a more accurate perception.

\section{Abstraction}

Confronted by a world of constant change, and by the need to analyse the world as a totality, the methodology adopted by Marx was one of abstraction. This approach is described by

Smith (1993, p. 4) as 'systematic dialectics'. This comprises the analysis of 'a progression of categories that moves in a step by step fashion to progressively more advanced determinations' (Smith, 1993, p. 55). This methodology comprises the focusing on those aspects most relevant for the subject of study. 
For Marx, in attempting to understand the capitalist system this involved, in the first instance distinguishing between those features of society that were immediately relevant, and those that were less relevant. As Ollman (2008, p. 16) argues, 'by starting with the decision to exclude all non-capitalist levels of generality from his awareness... Marx avoids tripping on what human society or class history or the other levels mentioned have placed in his way in carrying out his work as the systematizer of capitalism.' According to Ollman (2008, p. 1617) the frequent criticism of Marx that he overlooks other forms of exclusion such as race or gender misses the point, as these pre-date capitalism, and therefore 'cannot be part of what is distinctive about capitalism.' The point of the critique however, is to suggest the difficulty of understanding the distinction of capitalist processes when they are so much bound up with the systemic imperatives of ethnic and gender structuring. The debate about analytic distinction and relevance is still very much with us, for example, in contemporary debates in feminist theory. There are frictions between those accounts of gender which insist on the inseparable nature of race, class, gender and other differences (Haraway, 1989, 1991) and those engaged with analytic separation prior to an examination of interlinked processes (Marx-Feree, 2012; Walby, 1990, 2009). It is interesting to note that the approaches eschewing conflationary analytics have themselves been influenced by complexity thinking.

Marx's own systematic analysis proceeds through a number of steps, moving from the highly abstract, and moving towards the more 
concrete - or as Teschke and Heine (1996, pp. 411-412) call it 'concrete totality'.

Having isolated the key features of capitalism, Marx's next move is to consider the character of the interactions between these elements. Crucially, for Marx, capitalism is an inherently dynamic system which links features within the totality - 'conditions never come into Marx's study without umbilical ties to the people who affect and are affected by them' (Ollman, 2008, p. 17). Capitalism is a restless expansive force, with competition between capitalists being the force which encourages capitalists to constantly innovate in their drive to maximize profits (Harvey, 2000, pp 21-40). Marx's next step is to consider what needed to exist in the past to bring about what exists in the present. 'What Marx uncovers in his reconstruction of the present ... guides him in his search into the past, helping him decide what to look for as well as how far to go in looking for it' (Ollman, 2008 , p. 17). The final step that Marx takes, having considered the present, and how that emerged from the past is to reconstruct the forces in the present as contradictory elements, and to project those contradictory features into the future. Contained in this analysis is a consideration of the social forms that make the persistence of capitalism unlikely (for example a tendency for the rate of profit to fall), together with those elements that suggest that socialism is 'becoming increasingly practical, rational, conceivable, necessary, and even obvious' (Ollman, 2008, p. 19). 


\section{Complexity Thinking and Dialectics}

Thus far we have summarized our view of the main elements of dialectical thinking. In this section we compare dialectics to complexity approaches. One thing that these two approaches certainly share is a lack a single viewpoint as to what they comprise. Elsewhere (Cudworth \& Hobden, 2009), we have summarized four ways in which complexity thinking has been approached in the social sciences. Our approach draws in particular on the work of Morin, and Gunderson and Holling together with their various associates (see Cudworth \& Hobden, 2011). We prefer to use the more general term complexity thinking rather than the term complexity theory, because there is no one complexity theory, rather, a broad range of complexity approaches, which share some common concepts. Here we will give a brief summary of three concepts that we see as core to complexity thinking (complex adaptive systems, self-organisation and emergence) before moving on to see where there are overlaps with dialectical thinking, and where there are differences.

\section{Features of Complexity Thinking}

Central to complexity thinking is the complex adaptive system. Systems thinking has, perhaps understandably, been the target of considerable criticism. In the work of sociologists such as Parsons (1951, 1960), and the International Relations theorist Waltz (1979) systems have been seen as fixed, closed, and tending towards 
equilibrium. Complex adaptive systems, by contrast can be perceived as open, dynamic, and both potentially capable of moving closer to equilibrium as well as potentially moving away. From this perspective we live in a 'world of systems' (Bunge, 1979). Everything above the level of the most elementary particles is a system, and the environment for any one system is provided by all other system. We live in a totally interconnected universe, even if connections with some systems are rather minimal. Systems can therefore be considered as a boundary, although systems intersect and overlap with each other. An example would be a human body. A human body comprises many systems in itself. It absorbs other systems as food, and affects and is affected by a whole range of other systems.

Complex adaptive systems are perceived as open in the sense that they have permeable borders which can be traversed by other systems. The human body for example can be invaded by viruses. Complex adaptive systems are inherently dynamic in that they are constantly in a process of interaction in with their environment. They are also subject to processes of feedback - which can be stabilizing (negative feedback), or can lead systems away from equilibrium, potentially to such an extent that the system collapses, or flips to an alternate state.

A significant feature of complex adaptive systems is that developments, both within and between systems are viewed as being non-linear. A small change can have a disproportionately large and 
unpredictable outcome, whilst large effects can lead to minimal changes in systems.

A final feature that we mention is that the overlapping and intersected character of complex adaptive systems permits the analysis of multiple forms of exclusion. For example, in her work on globalization Walby (2009) develops an analysis of the multiple ways in which globalization processes have impacted on groups in society.

A second element of complexity thinking is the idea of selforganisation. In complexity thinking this is regarded as an inherent tendency in matter. The most extreme example of this would be the transition from the soup of elementary particles that appeared at the time of the big bang, to the human brain. For complexity thinking there is an assumption that same sort of processes are at work in the social world. The character of these processes is open to debate, with some (for example, Capra, 2002) suggesting that there is a continuity between human and non-human systems, while others suggest that as 'human beings are sense making animals' (Westley et al, 2002, p.108) that we need to think about social world differently.

It is this tendency towards self-organisation that underlies the processes which lead to the appearance of complex adaptive systems. The notion of a complex adaptive system provides the corner stone of complexity thinking, while self organization suggests that there is an inherent tendency for matter to organize in increasingly complex forms. The link between these two features is emergence, which 
provides a way of thinking about the character of the whole/part relationship.

Emergence refers to the unpredictable character of features which appear at the system level. In complex adaptive systems it is argued that the features at the system level will not only be more than the sum of the parts, they will also not be predictable from looking at the parts of a system. Higher levels of a system are dependent on the parts but not reducible to them. For example, consciousness is seen as an emergent feature of the brain, the features of which couldn't be derived from simply looking at the physical elements of the brain.

Having laid out some elements of a complex approach, we now turn to thinking about the similarities and differences with dialectical thinking.

\section{Points of Overlap}

In this section we draw attention to two points of overlap between dialectic and complexity thinking, namely the analysis of a totality, and the centrality of change.

Both dialectical thinking and complexity thinking perceive the necessity of an analysis that includes an awareness of what might be called a totality. For both forms of analysis this is a reaction to what might be called positivist, scientific, or reductionist thinking. In other words, it is not possible to break the world up into discrete elements and analyse these separately. In this sense there are no discrete units, 
and any attempt to understand discrete units would be limited because of a lack of knowledge about the context in which they operate, and the impacts of the environment in which they operate. While it may appear to make sense for the social sciences - confronted as they are by a world of innumerable actors and interactions - to operate a disciplinary division of labour, for both complexity thinking and dialectical thinking such a separation makes no sense. In addition, such a division of labour may have the result of producing limited or inaccurate information. An example might be the attempt to develop an understanding of economics outside of a social and political context. We might also add that it is impossible to understand economics outside of an ecological context. Likewise, an individual cannot be understood as separate from the society, or the individual's impact on society.

In our discussion of dialectics, we noted that what constitutes the totality was not always clear. However for complexity thinking it is apparent that by totality it really is totality that is meant. The environment for any one system is made up of all other systems, and crucially, due to non-linearity, minor happenings even in distant systems can major implications. This extends beyond the human and social world to non-human systems, both animate and inanimate. With its analysis of overlapping and intersected systems complexity thinking allows the possibility of developing an analysis where the human world is perceived as embedded within non-human systems of varying kinds. So, for example, the inter-relations between human 
systems and climatic systems can be analysed as well as taking into consideration impacts that this has on other species. The implications of this are problematic for analysis in complex systems. An implication of the view that distant minor events can have major local impacts comes the awareness that, in a situation of almost infinite systems, that there is a large element of unpredictability. From an analytical point of view this is problematic, particularly if the criteria for the assessment of perspectives is their ability to predict. This is a point to which we will return later.

A second area with which there is considerable agreement between complexity and dialectical thinking is the condition of change. Both approaches see the world as being in a constant state of flux. As with the view of the necessity of considering the analytical totality, this can be seen as an explicit challenge to positivist thinking. Rather than an expectation that it is possible to establish regularities, the understanding of both complex and dialectical thought is that there are unlikely to be regularities, or that any regularities are likely to be short lived.

The notion of change and the attempt to understand such a change is central to both complexity and dialectic approaches, and as we will see they have different ways of attempting to understand this change. The analysis of change relates to the analysis of the totality or system, and change can occur at any level. Both complexity and dialectical thought can be seen as historical approaches, attempting to 
understand how develops in the past generated the current day circumstances.

For both there is a view that the processes of change are neither smooth nor continuous. Hegel captured this notion with the view that there is a 'transformation of quantity into quality' - that small, perhaps imperceptible changes will at some point translate into a change of attributes. Complexity theorists describe this as a 'tipping point' or a 'phase change', referring to the point at which the characteristics of a system change undergo a radical transformation, or collapse. Such revolutions can be both sudden and unpredictable.

While there is an underlying expectation of the possibility of radical and unpredictable change to both forms of thinking, for complexity thinking the future would appear to be much more open than for dialectical thought. In the discussion of dialectics earlier, Ollman suggested that part of the methodology was to identify those elements of a socialist future that existed in present arrangements. Complexity thinkers would certainly agree that the conditions for the future would be found in the present, but would be much more cautious about how those conditions could be pursued to encourage a more equitable future - while accepting that such a future is both possible and desirable. Here a central contribution of complexity thinking would be that in moving towards a sustainable and equitable future there is a need to take in and deal with a world of complexity. In Morin's (2008, p. 96) words we need to develop 'the art of working with uncertainty'. An important element of complexity thinking then is 
to develop notions of how practice may be organised under conditions of complexity. Law and Urry (2004), for example, have considered the possibilities of a project in which we 'enact the social'.

As we will see in the next section dialectical and complex thought have different views on what drives such change and whether such change has a particular direction, and perhaps end point. However it is an expectation of both that change is a central feature of existence.

Points of contention.

In this section we raise three points of contention between complexity and dialectical thinking: contradiction, teleology, and anthropocentrism.

As we saw earlier contradiction is at the heart of dialectical thinking, and this is a view that is supported by most commentators on this approach [but not all]. Complexity thinking would accept absolutely that there are contradictions in society, and also that there are multiple forms of social exclusion. A central element of Walby's (2009) work on globalization, for example has been to use complexity thinking to highlight multiple forms of social exclusion. The point that complexity thought would challenge is that this is the only way in which change and flux can be understood. Bunge $(1979$, p.125) for example, argues that the view that 'all change comes from the "contradiction" or "struggle"... is falsified by all the cases of 
cooperation both in nature and society.' Such a framework based on contradiction has been at the heart of much critical theory (broadly defined) but is based on a partial reading of The Origin of Species. This, influenced more by the writings on human evolution of T. H. Huxley, very much underplays Darwin's meticulous picture of ecological interrelatedness in which hybridity, variety and 'mutual affinities' play as much of a role as selection and the 'struggle for existence' (see Darwin, 1998).

A different trajectory to both Marx and Hegel was pursued by Kropotkin in his work on mutuality. Kropotkin wrote in response to such Huxleyan accounts of Darwin that focussed on the survival of the fittest. Kropotkin's view was that this was only one interpretation of the processes of evolution. For example, Kropotkin's research in East Asia led him to speculate on the ways in which Darwin's theory had been interpreted. Kropotkin argued that there was evidence of mutuality between species in addition to competition. As far as Kropotkin (1987 [1902], p.24) was concerned 'sociability is as much a law of nature as mutual struggle'. Human beings, Kropotkin (1987 [1902], p.43) argued, could not have reached their high level of development without a high level of co-operation, particularly given their vulnerability compared to other non-human animals.

Complexity thinking usually depicts this as the idea of coevolution. Interactions between complex adaptive systems can result in dynamic changes in both without one being subsumed into the other. One example of such a process related to interactions between 
animate and inanimate systems is the recent research that suggests that the use of tools by early humans led to increases in brain sizes which in turn led to the development of more intricate tools (Spier, 2010 , p. 121). This could be seen as a non-contradictory relationship between two systems which led to a development of both. Similar arguments have also been made with respect to the animate nonhuman world. Haraway's work on historically evolving relations between humans and dogs, for example, suggests a history of codomestication (Haraway, 2003; 2008). The evolution of human lifeways and survival practices (ensuring security from predation, obtaining food and so on) have been seen as a development of coevolution with particular canid social systems (see Clutton-Brock, 1981, 1995). In addition, it may be argued that such developments are les straightforward and that interactions between human and nonhuman social systems might be characterised both by contradiction (in terms of the predominance of human interests in exploiting the labour of dogs for security and hunting), and co-evolution (as companions species sharing dwelling places in relations of reciprocity) (see Cudworth, 2010, p. 152-3).

As well as co-evolution a further concept that is used within complexity thinking to understand change without contradiction is the idea of feedback. In particular, positive feedback - which takes systems further away from equilibrium positions, as opposed to negative feedback which acts to stabilise systems - can result in systems tipping into a different form. For example, there has been 
much recent concern about positive feedback loops with regard to climate change. There is a concern that rising temperatures due to increased levels of carbon dioxide will lead to the thawing of arctic tundra releasing further greenhouse gases causing further temperature rises (Heimann and Reichstein, 2008).

While complexity thinking does not exclude the use of contradiction as a form of analysis, and we would certainly agree that capitalism as a complex adaptive system is mired in contradiction, our point is that this is not the only way to understand processes of change. Following Kropotkin we would argue that human society has not solely developed as a result of the working out of contradiction there is mutuality as well as co-operation. Furthermore complexity concepts such as co-evolution and feedback contribute ways of analysing change which isn't always on the basis of contradiction.

The second area we would see a difference between complexity thought and dialectics is with regard to teleology. There can be little doubt that Hegel's dialectical thinking was teleological, in particular with the notion of an 'end of history', and absolute spirit. We are persuaded that Marx can certainly be interpreted in a non-teleological way. It is perhaps worth pointing out however that Marx, in line with much nineteenth century thinking, did have a stage-ist and progressive view of history. Additionally certain features of capitalism appear to be regarded as having qualities of inevitability. 
Our concern, however, is that there is a teleological legacy from Hegel that dialectics finds hard to shake off. Titles of significant Marxist analyses of dialectics such as Rees' The Algebra of Revolution, and Ollman's Dance of the Dialectic suggest that there is rather more of a pattern to dialectical processes than complexity thinking would be comfortable with. Smith (1993, p. 92, emphasis added) points to the teleological aspects of Marxist dialectics in drawing a comparison with the Hegelian approach to history:

For Marx history ultimately is not a process of the unfolding of spirit, but rather a sequence of modes of production... the form of their historical theories is quite similar. For Marx each mode of production plays a necessary role in the development of the human species... It [dialectics] remains a methodology by means of which each stage is assigned its necessary role in a teleological process of development.

Ultimately the process within dialectics of contradictions moving the historical process appears to imply a forwards motion. This was certainly the case in Hegel, and may have become embedded within dialectical thinking more generally. In a related statement discussing Marx's methodology Ollman (2008, p. 16) notes that 'Marx sought to steal the secret of the future from its hiding place in the present.' This statement also implies a level of predictability of the future. Bunge (1979, p. 129) criticises this tendency towards the prophetic in Marxism by noting that 'we have learned at great social cost that nothing in evolution, whether social or biological, is inevitable: there are accidents of all kinds as well as unpredictable innovations.'

Inherent in the complexity approach is a rejection of all 
teleology and determinism (Cudworth and Hobden, 2012, pp.177178). In a world of non-linear relations and multiple over-lapping and intersected systems it is the unexpected that is to be expected rather than the anticipated. As Elliott and Kiel (1997, p. 68) suggest, 'Nonlinear dynamics ... lead us to question the extent to which we may be capable of both prediction and control in social and policy systems.' From this perspective the important issue is to deal with living with complexity, and the need to take this into account in the consideration of alternate futures.

The final difference between dialectical thinking and complexity approaches is that the former, in common with much thinking in the social sciences, tends to take an anthropocentric approach. While complexity thinking does not necessarily escape from anthropocentrism, our position is that, given the analysis of embedded and overlapping systems, it implies and allows for, the development of non-anthropocentrism (Cudworth \& Hobden, 2013a). Hegel's analysis of dialectics was clearly human-centered, and focussed as we saw earlier on the development of human consciousness. His philosophy of history was a canonical example of a hegemonic cultural model which bound humanism to a conception of European civilization. This, in turn, was coincidental with 'the universalizing powers of self-reflective reason' (Braidotti, 2013, p. 13). However, if the non-human world is understood as both self-organising and as co-evolving; and if humans are understood as embedded in and constitutive of configurations of 'natureculture' (Haraway, 1997); then Hegel's model of dialectics is 
certainly a limited, partial one, and very much a project of European liberal humanism (see Spivak, 1999).

As with the question of teleology there is more debate over what might be termed the 'nature' question in Marx's works - and there would certainly seem to be indications that Marx viewed humanity as part of nature. By moving the focus of the dialectic onto the material would also suggest the possibility of overcoming a human/nonhuman nature divide. However Marx would appear to share, with Hegel, the view that a feature that distinguishes humans as a species was work. As Sayers $(2003$, p. 110) notes 'work is a mode of this practical being-for-self and a means by which it develops. Work involves a break with the animal, immediate, natural relationship to nature. In work, the object is not immediately consumed and annihilated. Gratification is deferred. The object is preserved, worked upon, formed and transformed. And, in this way, a distinctively human relationship to nature is established.' This, then, is a partial ontology of the material. The range of (new) materialist approaches have, despite significant differences in approach and focus, suggested a more radical embedding of the human animal in the multifarious relational systems and processes of the non-human lifeworld (see Connelley, 2013; Cudworth and Hobden, 2013b). In the process, some have argued that the development of more inclusive materialisms involves the abandoning of dialectics as a mode of analysis hopelessly mired in an exclusive form of humanism (see for example, Braidotti, 1991). Pheng Cheah (2008) uses the phrase 'nondialectical 
materialism' to counter pose the materialism of Marx with that of Deleuze and Derrida. He considers that the problem with the reduction of the material to labour is a more general problem of negation. In suggesting that human beings indirectly produce actual material life when we produce our means of subsistence through labour, Marx implies that material reality is produced by negativity (Cheah, 2008, p. 144). A move away from the primacy of negation, for Cheah, is the linchpin of a non-dialectical materialism. As we have suggested above however, it is not necessary to abandon contradiction entirely with the use of complexity analytics. Rather, material change may be characterised by mutuality or by both contradiction and mutuality (as in the case of companion species co-evolution).

We would concur that such a focus on labour, and the humancentric production of the material entirely through negation is problematic, however. Hence, as is also frequently discussed, Marx centred his analysis on production and on the social relations that surround this - so it is unavoidable with this as a focus that the approach would be human centred. Marx's perspective on labour, Smith (2001, p. 87) argues 'limits what can and can't be said about nature and it is because of this emphasis on the dynamics of human labour that nature finds itself marginalized in spite of Marx's materialism.' Thus nature's role in the production process is to be consistently dominated and subordinated by human activity, as implied in Marx's (cited in Smith 2001, p. 88) statement that 'the labour process is an appropriation of what exists in nature for the 
requirements of man.' Nature, in this account would appear to be a resource to be drawn upon to fulfil human requirements.

The non-dialectical materialism of Cheah and others (Braidotti, 2002) is not, however, a path we would necessarily recommend.

Derridarian deconstruction is often profoundly immaterial - focusing (albeit critically) on the human productions of language and text (see Calarco, 2008, p. 148-9). The dynamic, fluctuating, enlivened world of Deleuzian (new) materialists such as Cheah certainly appreciates the embedding of the human animal in a world of non-human beings and things (see Bennett, 2010). Yet it is also unable to account for the very kinds of power relations with which the materialism of Marx was so crucially concerned. Our version of posthumanist materialism draws on complexity thinking in order to account for power as oppressive and exploitative as well as (re)productive. Our relations with nonhuman systems are of overlapping lifeways and entangled lives, and of co-evolved histories. Yet the systemic relations of capitalism, colonialism and patriarchy have fundamentally shaped the ways things are and the processes of their becoming so. Here, our critique of Marx was that his incredible interventions never realised the potential of an important claim in his earlier works that 'Man [sic] lives from nature, i.e. nature is his body, and he must maintain a continuing dialogue with it if he is not to die' (Marx, 1975, p. 327).

\section{Conclusions}


Dialectics, as broadly perceived, represents a challenge to positivist and mechanical accounts of the social world. Existence is perceived as comprising numerous elements in as state of constant interaction and change. Attempts to analyse that focus on a specific element in an unchanging form will lead to limited perceptions. Thus far complexity thinking would be in total agreement with dialectical approaches. Where the differences emerge are primarily in the area of contradictions, teleology and anthropocentrism. These points, we would argue, certainly hold for Hegelian dialectics, though are more disputable with regard to Marx's use of dialectics. The question is to what extent the Hegelian legacy hangs over attempts to take dialectics in a non-teleological, non-anthropocentric and able to accept mutuality in addition to contradiction. If such an approach is seen as contributing to dialectical thinking then an engagement with complexity thought could provide a means of developing such an approach.

\section{References}

Brincat, S. (2010). Towards a social-relational dialectic for world politics. European Journal of International Relations, 17, 679-703. Buchwalter, A. (2012). Dialectics, politics, and the contemporary value of Hegel's practical philosophy. London: Routledge.

Bunge, M. (1979). Treatise on basic philosophy, volume 4: A world of systems. Dordrecht: D. Reidel.

Braidotti, R. (1991). Patterns of dissonance: A study of women in contemporary philosophy. Cambridge: Polity. 
Braidotti, R. (2002). Metamorphoses: Towards a materialist theory of becoming. Cambridge: Polity.

Braidotti, R. (2013). The posthuman. Cambridge: Polity.

Butler, C. (2012). The dialectical method: A treatise Hegel never wrote. Amherst, NY: Prometheus.

Calarco, M. (2008). Zoographies: The question of the animal from Heidegger to Derrida. New York: Colombia University Press.

Cheah, P. (2008). Nondialectical materialism. Diacritics 38, 143-57.

Clutton-Brock, J. (1981). Domesticated Animals from Early times. London: Heinemann.

Clutton-Brock, J. (1995). Origins of the dog: Domestication and early history. In J. Serpell (ed.), The domestic dog: Its evolution, behaviour and interactions with people (pp.8-20). Cambridge: Cambridge University Press.

Creavan, S. (2007). Emergentist Marxism: Dialectical philosophy and social theory. London: Routledge.

Cudworth, E. (2011). Social lives with Other animals: Tales of sex, death and love. Basingstoke: Palgrave.

Cudworth, E. \& Hobden, S. (2009). More than a metaphor?: Complexity in the social sciences. International Journal of Interdisciplinary Social Sciences, 4, 59-70.

Cudworth, E. \& Hobden, S. (2011). Posthuman international relations: Complexity, ecologism and world politics. London: Zed.

Cudworth, E. \& Hobden, S. (2012). The foundations of complexity, the complexity of foundations, Philosophy of the Social Sciences, 42, $163-$ 187.

Cudworth, E. \& Hobden, S. (2013a). Complexity, ecologism, and posthuman politics. Review of International Studies, 39, 643664.

Cudworth, E. \& Hobden, S. (2013b). Of parts and wholes: International relations beyond the human. Millennium, 42, 430-450.

Darwin, C. (1998). The Origin of Species. (Ware: Wordsworth). 
Elliott, E. \& Kiel, L. D. (1997). Nonlinear dynamics, complexity, and public policy: Use, misuse, and applicability. In R. A. Eve, S. Horsfall, \& M. E. Lee (eds.), Chaos, complexity, and sociology (pp. 64-78).

London: Sage.

Gray, J. (2002). Straw dogs (London: Granta).

Haraway, D. (1997).Modest_Witness@Second_Millennium.

FemaleMan_Meets_OncoMouse London: Routledge

Haraway, D. J. (2003). The companion species manifesto: Dogs, people and significant otherness. Chicago: Prickly Paradigm Press.

Haraway, D. J. (2008). When species meet. Minneapolis MN: University of Minnesota Press.

Harvey, D. (2000). Spaces of hope. Edinburgh: Edinburgh University Press.

Heimann, M. \& Reichstein, M. (2008). Terrestrial ecosystem carbon dynamics and climate feedbacks. Nature, 451, 289-92.

Jameson, F. (2008). Persistencies of the dialectic: Three sites. In B. Ollman \& T. Smith (eds.), Dialectics for the New Century (pp. 118 131). Basingstoke: Palgrave.

Kovel, J. (2008). Dialectics as praxis. in B. Ollman \& T. Smith (eds), Dialectics for the new century (pp. 235-242). Basingstoke: Palgrave.

Kropotkin, P. (1 987 [1902]). Mutual aid: A factor of evolution. London: Freedom Press.

Law, J. \& Urry, J. (2004). Enacting the social, Economy and Society, 33, 390-410.

Livant, B. (2008). The dialectic of walking on two legs. in B. Ollman \& T. Smith (eds.), Dialectics for the new century (pp. 132-134).

Basingstoke: Palgrave.

Marx, K. (1975). Early writings. Ed. L. Colletti. Harmondsworth: Penguin.

Marx, K. (1976 [1873]). Postface to the second edition of Capital, volume 1. London: Penguin.

Marx-Feree, M. (2012). Varieties of feminism: German gender politics in global perspective. Stanford, CA: Stanford University Press. 
Morin, E. (2008). On complexity. Cresskill, NJ: Hampton Press.

Ollman, B. (1993). Dialectical investigations. London: Routledge.

Ollman, B. (2008). Why dialectics? Why now? In B. Ollman \& T. . (eds), Dialectics for the New Century (pp. 8-25). Basingstoke: Palgrave.

Ollman, B. \& Smith, T. (2008). Introduction. In B. Ollman \& T. Smith (eds), Dialectics for the new century, (pp. 1-7). Basingstoke: Palgrave. Parsons, T. (1951). The social system. London: Routledge and Kegan Paul.

Parsons, T. (1960). Structure and process in modern societies.

Glencoe, IL: Free Press of Glencoe.

Rees, J. (1998). The Algebra of revolution: The dialectic and the classic Marxist tradition. London: Routledge.

Sayer, S. (2003). Creative activity and alienation in Hegel and Marx. Historical Materialism, 11, 107-128.

Smith, T. (1993). Dialectical social theory and its critics: From Hegel to analytical Marxism and postmodernism. New York: State University of New York Press.

Smith, M. (2001). An ethics of place: Radical ecology, postmodernity and social theory. Albany NY: State University of New York Press).

Spier, F. (2010). Big history and the future of humanity. Oxford: WileyBlackwell.

Spivak, G. (1999). A critique of postcolonial reason: Towards a history of the vanishing present. Cambridge, MA: Harvard University Press. Tesche, B. \& Heine, C. (2012). Sleeping beauty and the dialectical awakening: On the potential of dialectic for international relations. Millennium, 25, 399-423.

Walby, S. (1990). Theorizing patriarchy. Oxford: Blackwell.

Walby, S. (2009). Globalization and inequalities: Complexity and contested modernities. London: Sage Publications.

Waltz, K. (1979). Theory of international politics. New York: Random House. 
Westley, F. et al (2002). Why systems of people and nature are not just social and ecological systems. In L.H. Gunderson and C.S. Holling (eds.), Panarchy: Understanding transformations in human and natural systems (pp. 103-120). Washington DC: Island Press.

Wood, A. (1993). Hegel and Marxism. In F. C. Beiser (ed.), The Cambridge Companion to Hegel (pp. 414-444). (Cambridge:

Cambridge University Press). 